\title{
Gingival Tissue and Pregnancy
}

\author{
Gloria Inés Lafaurie \\ Director Oral Basic Research Unit- UIBO \\ Associate Professor, Universidad El Bosque, \\ School of Dentistry Bogotá \\ Colombia
}

\section{Introduction}

During pregnancy, many changes take place in both systemic and local environments leading to a significant increase in the severity of gingivitis. In recent years, many studies have assessed the changes that occur within the gingival tissue during pregnancy and their potential impact on the foetus.

Pregnancy is defined as a state that includes fertilization, implantation and embryonic and fetal growth that ends with the birth of a baby after 280 days or 40 weeks. Pregnancy gingivitis presents as gingival erythema, enlargement and bleeding. Epidemiological studies have shown that the prevalence of gingivitis increases during pregnancy when compared to control groups. The evidence indicates that hormonal changes affect the rate of cell turnover of the gingival tissues, inducing several microbiological changes in the subgingival flora and immunosuppression of the immune system.

New evidence supports an association between the periodontal status and complications during pregnancy. Some countries have developed policies and practice guidelines that recommend oral care and the control of inflammation of the periodontal tissues throughout pregnancy.

This chapter will review the effect of pregnancy on gingival status and the potential impact of gingival inflammation on the unborn child.

\section{Pregnancy gingivitis}

Pregnancy is accompanied by an increase in the production of estrogen and progesterone. Initially, the ratio of estrogen and progesterone is 100:1 but during the final months this changes to 1:1. Following birth the hormones reach their normal levels within 2 to 3 days (Mariotti 1994, Laine 2002).

Two theories have been proposed for the actions of the hormones on the cells of the periodontal tissues: 1) a change in the effectiveness of the epithelial barrier to bacterial insult and 2) an effect on collagen turnover (Markou et al. 2009). There are several receptors for estrogen and progesterone within the gingival tissue. The estrogen receptors (ERs) exist as two subtypes: ERalpha and ERbeta. ERbeta is widely expressed at high levels in oral tissues (Välimaa et al.2004). ERbeta is involved in important physiological processes, such as cell differentiation, extracellular matrix organization and stromal-epithelial communication 
(Morani et al. 2008). Estrogen firstly decreases collagen production and keratinization of gingival epithelium and secondly induces proliferation of fibroblasts and decreases the collagen and no collagen proteins, blocks the turnover of the gingival tissue, thereby reducing the capacity of gingival tissue to repair. The result is an increase in the permeability of the epithelial barrier and an increased response to plaque bacteria. (Markou et al. 2009). Liu et al. (1999) observed a decrease in cellular proliferation of the periodontal ligament (PDL). In addition, a decrease in the rate of collagen is mediated by ERbeta. In contrast, no immunoreactivity was expressed in these cells for progesterone receptors, implying that progesterone does not have a direct effect on the function of PDL cells (Jönsson 2007).

The reactivity for progesterone receptors was observed in gingival fibroblasts (Kawahara \& Shimazu 2003). Progesterone also has effects on the vascular system favoring an increase in gingival exudate and vascular permeability and proliferation; this is possibly due to progesterone receptors present in the gingival tissue (Markou et al. 2009). Other factors associated with the tissue changes during pregnancy are those related to the fibrinolytic system. Fibroblast and macrophages from gingival tissue produce plasminogen activator inhibitor type-2 (PAI-2). Several studies had suggested a hormonal influence on the PAI-2 that disturbs the balance of the fibrinolytic system. A lower inhibitory capacity in terms of a low production of PAI-2 associated with progesterone during pregnancy in women with a higher inflammatory reaction has been observed and could contribute to gingivitis during pregnancy (Kinnby et al.1996).

\section{Pregnancy and the subgingival microflora}

Pregnancy is accompanied by many changes in the composition of the subgingival microflora. Jensen et al. (1981) and Korman and Loesche $(1980,1982)$ showed that Prevotella intermedia and Prevotella meloninogenica, use either estradiol or progesterone as a substitute for napthaquinone (Jensen et al. 1981) and vitamin K (Korman \& Loesche 1982), as essential growth factors which encourage a proliferation of these microorganisms in subgingival plaque during pregnancy.

The correlation between the concentration of hormones in saliva and changes in oral microflora during pregnancy are summarized in Table 1. These data provide further support for the fact that hormonal changes during pregnancy promote microbiological changes in the subgingival flora. Most of these studies found a positive correlation between an increase in estradiol and progesterone and an overgrowth of P.intermedia (Korman \& Loesche 1980, Muramatsu \& Takaesu 1994, Gursoy et al. 2008, Carrillo-de-Albornoz et al. 2010). A positive correlation was also observed between an overgrowth of Porphyromonas gingivalis, Tannerella forshytia (Andriens et al. 2009) and Campylobacter rectus and an increase in estradiol concentrations. (Yokoyama et al 2008).

It has been suggested that microbial changes observed during pregnancy may also occur at other sites in the body. High microbial counts in the vagina have been correlated with gingivitis in pregnant women when compared with patients without gingival inflammation (Person et al. 2009). Correlations between microbiological changes and increased gingival inflammation have also been extensively studied. The subgingival microflora increased from week 12 of pregnancy, was maintained during the second quarter and reduced during the third trimester to postpartum (Korman \& Loesche 1980, Muramatsu \& Takaesu 1994, 
Yokoyama et al. 2008, Andriens et al. 2009). However, some studies had shown that these changes can be maintained throughout pregnancy (Gürsoy et al. 2009, Carrillo-de-Albornoz et al. 2010). Most of the studies agree that the increase in gingival inflammation occurs in the second quarter and is associated with an overgrowth of $P$. intermedia, (Korman \& Loesche 1980, Muramatsu \& Takaesu 1994). A correlation was also observed between an increase in gingival bleeding and an increase in P. gingivalis and T. forsythia (Andriens et al. 2009). After delivery, the levels of bacteria are reduced although, these changes can be sustained between 4 to 6 weeks postpartum (Gursoy et al. 2008, Andriens et al.2009). The evidence supports the fact that clinical changes during pregnancy are associated with changes in the subgingival flora. However, other factors such as an impairement of cellular function and immunological changes may also contribute to the increased severity of gingivitis in pregnancy. (Figure 1, Figure 2).
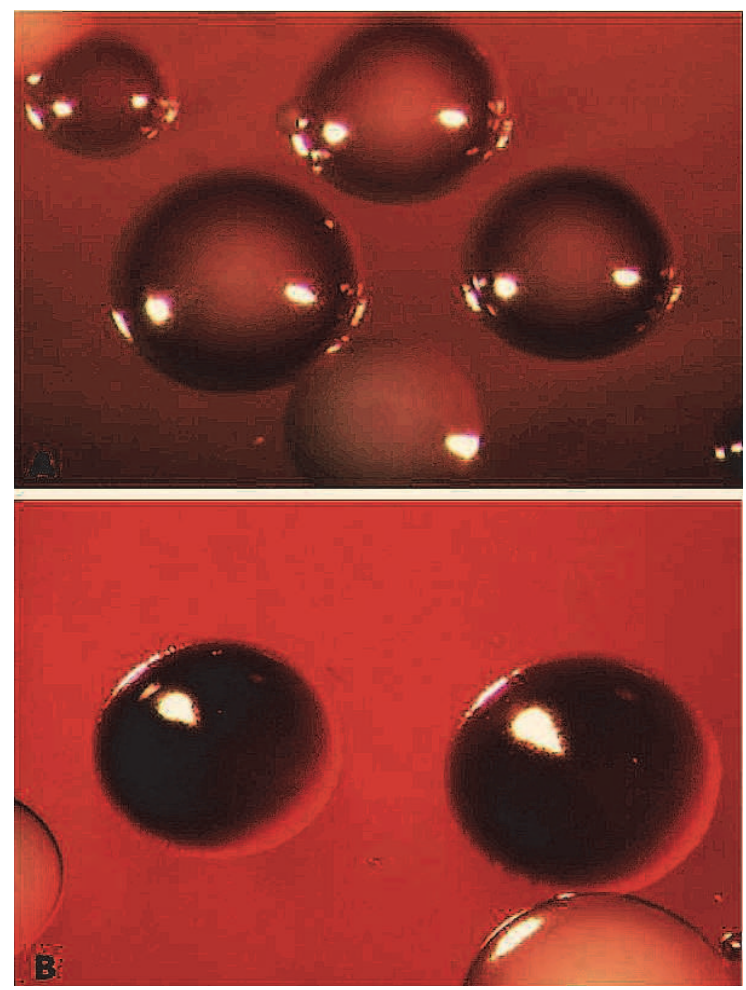

Fig. 1. A. Prevotella intermedia isolated from a pregnant patient. (Oral Basic Research UnitUIBO, 2010 used for reseach purposes) 


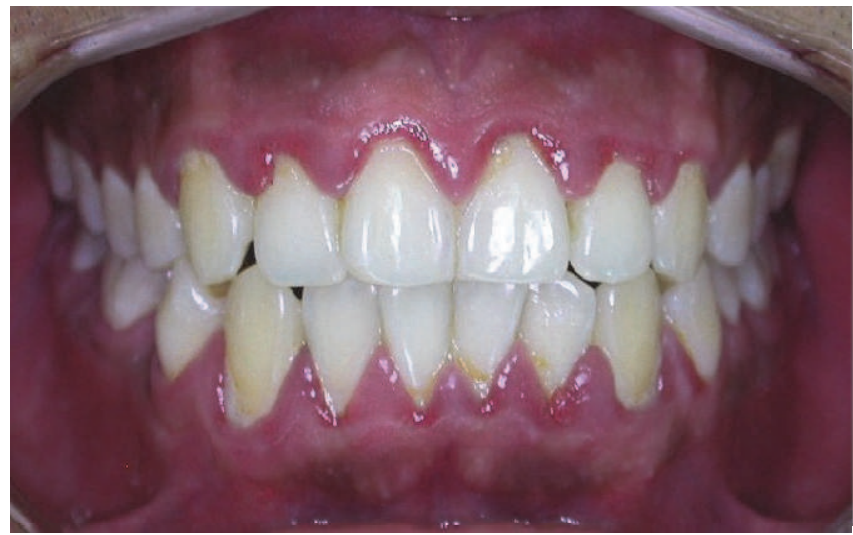

Fig. 2. Severe gingival changes in a woman with heavy plaque deposits during the second trimester (School of Dentistry, Universidad El Bosque, 2010. Used for academic resources)

\begin{tabular}{|c|c|c|c|c|c|c|}
\hline Authors & Population & $\begin{array}{l}\text { Design } \\
\text { of Study }\end{array}$ & Hormone & $\begin{array}{l}\text { Clinical } \\
\text { changes }\end{array}$ & Time & Microorgnims \\
\hline $\begin{array}{c}\text { Korman \& } \\
\text { Loesche } 1980\end{array}$ & USA & $\begin{array}{c}\text { Cross } \\
\text { Sectional }\end{array}$ & $\begin{array}{c}\text { Estradiol } \\
\text { progesterone }\end{array}$ & Gingivitis & $\begin{array}{l}\text { Second } \\
\text { quarter }\end{array}$ & $\begin{array}{l}\text { P. intermedia } \\
\text { P.melanogenica }\end{array}$ \\
\hline $\begin{array}{c}\text { Muramatsu \& } \\
\text { Takaesu } 1994\end{array}$ & Japan & $\begin{array}{c}\text { Cross } \\
\text { Sectional }\end{array}$ & $\begin{array}{c}\text { Estradiol } \\
\text { progesterone }\end{array}$ & Bleeding & $\begin{array}{c}3-5 \\
\text { month }\end{array}$ & P. intermedia \\
\hline $\begin{array}{c}\text { Yokoyama et al } \\
2008\end{array}$ & Japan & $\begin{array}{c}\text { Cross } \\
\text { sectional }\end{array}$ & Estradiol & Gingivitis & $\begin{array}{l}\text { Second } \\
\text { quarter }\end{array}$ & C. rectus \\
\hline Gursoy et al. 2008 & Finland & Cohort & No report & Gingivitis & $\begin{array}{l}12 \text { weeks } \\
\text { to end of } \\
\text { pregnancy }\end{array}$ & P. intermedia \\
\hline $\begin{array}{c}\text { Andriens et al. } \\
2009\end{array}$ & Switzerland & Cohort & $\begin{array}{c}\text { Estradiol } \\
\text { progesterone }\end{array}$ & Gingivitis & $\begin{array}{l}12-28 \\
\text { weeks }\end{array}$ & $\begin{array}{l}\text { P. gingivalis } \\
\text { T. forsythensis }\end{array}$ \\
\hline $\begin{array}{l}\text { Carrillo de } \\
\text { Albornoz et al } \\
2010\end{array}$ & Spain & Cohort & No report & Gingivitis & $\begin{array}{l}12 \text { weeks } \\
\text { to the end } \\
\text { of } \\
\text { pregnancy }\end{array}$ & $\begin{array}{l}\text { P. gingivalis } \\
\text { P. intermedia }\end{array}$ \\
\hline
\end{tabular}

Table 1. Clinical and Microbiological changes in subgingival plaque associated with hormonal changes during pregnancy. 


\section{Immunological changes during pregnancy}

Increases in progesterone and prostaglandins modulate the immune system during pregnancy. Some degree of immunosuppression occurs during pregnancy which minimizes the risk of fetal rejection (Hansen 1988). Maternal tolerance of the fetal allograft could be the result of the integration of numerous mechanisms promoted by different cells presented in the decidua. Decidual macrophages and dendritic cells, which are found in close association with $\mathrm{T}$ lymphocytes are the most potent activators of T-lymphocyte responses and could play a sentinel function for the immune system, initiating antigen-specific $\mathrm{T}$ cell responses to fetal antigens (Piccini 2005). Progesterone and glucocorticoids share important antiinflammatory and immunosupressive properties and both hormones have potent antiproliferative effects in mitogen activation and cytotoxic $\mathrm{T}$ cell generation (Stites et al. 1983). There is a decrease in CD4/CD8 ratio and peripheral blood lymphocytes and a low expression of HLA class I during pregnancy (Szekeres-Bartho et al. 1985). T cell cytokine profile could be modulated by the hormones present in the microenvironment; high doses of progesterone present at the feto-maternal interface and in the cumulus induce the production of IL-4, a strong inducer of Th2 profile which is anti-inflammatory. Progesterone also upregulates HLA Class I type G gene expression, which is the NK inhibitory ligand (Yie et al. 2006), supresses the proliferation of CD4+ lymphocytes (Bainbridge et al. 2000) and induces apoptosis in activated CD8+ Lymphocytes (Fournel et al. 2000). Progesterone also down-regulates IL-6 production, rendering the gingiva less efficient at resisting the inflammatory challenges produced by bacteria (Lapp et al. 2003). Estradiol and progesterone levels increase in saliva during pregnancy, reaching a peak in the third trimester. Levels of IL-1 beta and PGE2 showed no significant change in their concentration in crevicular fluid during pregnancy. Although their concentrations were higher than non-pregnancy women, they did not correlate with clinical changes in gingival tissue (Figuero et al. 2010). However, there was an increased concentration of IL1-beta, IL6 and PGE2 in plasma in pregnant women with periodontitis, indicating that the presence of the disease can lead to increased systemic inflammatory markers (Offenbacher et al. 1998, Ebersole et al. 2010). A decrease in neutrophil chemotaxis has been observed during pregnancy, which may be due to the effects of sex hormones (Miyagi et al. 1992). These changes in the immune system may explain the susceptibility to infection during pregnancy and can support the clinical observation of complications in pregnant women with periodontitis.

\section{Gingival changes during pregnancy and their treatment}

The prevalence of gingivitis during pregnancy has been studied in different populations. (Ainamo et al. 1982). Studies that have assessed the prevalence of gingivitis during pregnancy using the CPITN index are shown in Table 2. The prevalence varies between 67 to $100 \%$. In some studies, the prevalence and severity is higher in pregnant women when compared with non-pregnant women (Nuahma \& Annan 1998, Rakchanok 2010). However, Miyazaki et al.1991 observed no difference between pregnant and non-pregnant. Studies using the CPITN index reported that most pregnant women have calculus and gingival inflammation and few women have healthy gingiva during pregnancy. Most pregnant women have non-surgical treatment needs and oral hygiene instruction but very few require complex periodontal treatment (Table 2). Cohort studies support the evidence that pregnancy is associated with gingival changes, (Tilakaratne et al. 2000, Gürsoy et al. 2008, Carrillo-de-Albornoz et al. 2010). The clinical indicators evaluated in these studies were bleeding on probing and pocket depth without loss attachment, which indicated that this 
may be due to a more pronounced gingival overgrowth in the proximal surfaces of anterior teeth (see figure 2). Few studies have determined the correlation of detectable levels of plaque and gingival clinical changes. However, two studies reported the same level of dental plaque in pregnant and controls; however, pregnant women responded more severely to dental plaque than non pregnant women (Gürsoy et al. 2008, Carrillo-deAlbornoz et al. 2010).

The period between weeks 12 and 28 of pregnancy can be characterized by increased susceptibility to plaque bacteria and an inflammatory response in the gingiva (Adraiens et al. 2009). Studies have not observed loss of attachment during pregnancy, but any preexisting periodontitis is exacerbated.(Amar \& Chung 1995). Progesterone can reduce local production of matrix metalloproteinases and may explain why pregnancy gingivitis may not necessarily progress to periodontitis (Laap et al. 1995, Gursoy et al. 2010). Several cohort studies had shown that the loss of attachment can be observed during pregnancy and the predictor variables are depth of the pockets $>4 \mathrm{~mm}$ before week 26 weeks and presence of bleeding on probing (Moss et al. 2005). Thus, the loss attachment during pregnancy was not associated with pre-existing gingivitis, but with the presence of periodontal pockets when women became pregnant. During pregnancy, a significant change in tooth mobility can be also being observed. The initial mobility is dependent on the degree of vascularization and vascular volume of the periodontal ligament. When the female sex hormones act at high concentrations for prolonged periods, an increase in the permeability within the periodontal vascular system could occur. The resulting edema in the periodontal ligament may result in an increase in horizontal tooth mobility in the absence of any loss of periodontal support (Mealey \& Moritz 2003).

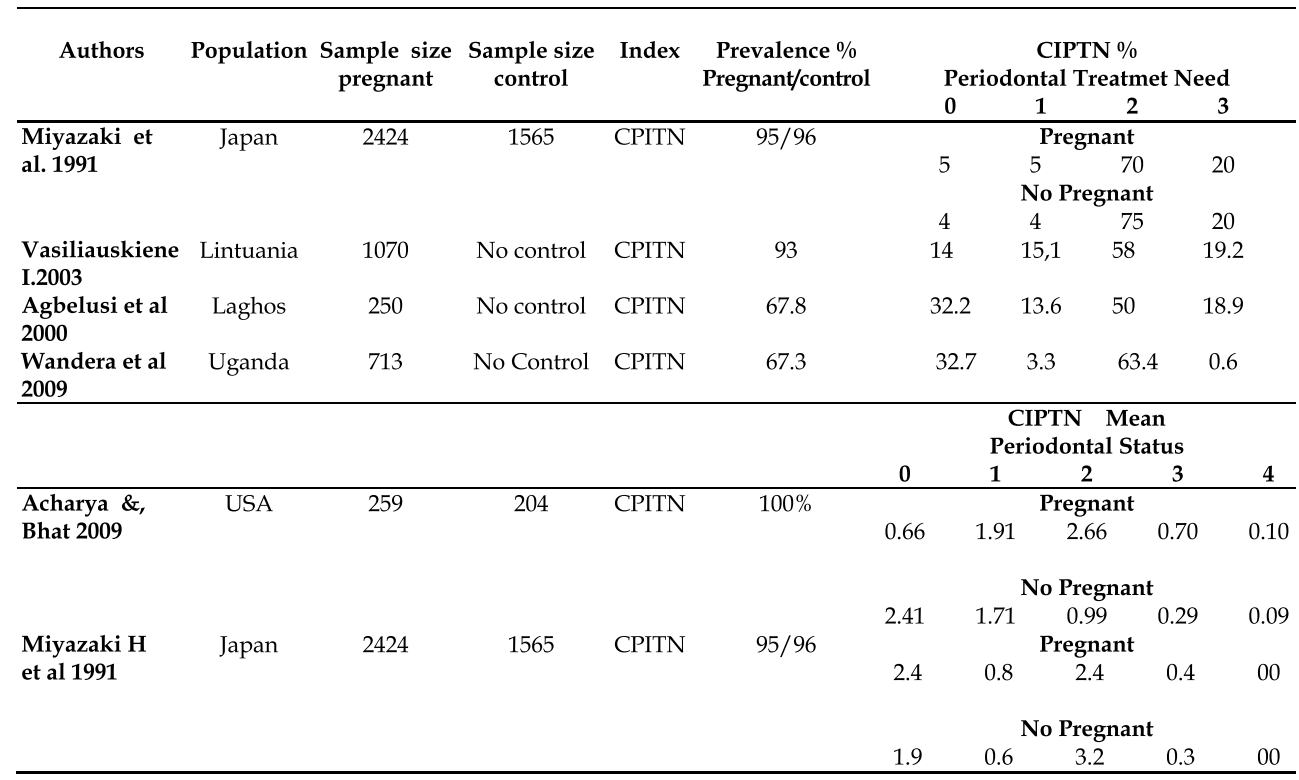

Table 2. Prevalence, Periodontal status and periodontal treatment needed in pregnant women. 
Another clinical feature that may arise during the latter stages of pregnancy is the socalled pyogenic granuloma, (pregnancy tumor or epulis). This occurs in 1 to $5 \%$ of pregnant women (Amar \& Chung 1995). These result from angiogenesis, caused by the increased levels of progesterone and the stimulatory effects of estradiol on the connective matrix. They usually arise in sites with pre-existing gingivitis (Jafarzadeh et al. 2006), and often involve the interdental papilla of one of the maxillary anterior teeth and rarely exceed $2 \mathrm{~cm}$ in diameter. When they persist they can be surgically remove and their removal should be delayed until after delivery. (Jafarzadeh et al. 2006, Rader et al.2008). Their removal during pregnancy may be justified if they are continuously traumatized. Ideally they should be removed using CO2 or Nd:YAG laser. (Powell et al.1994, Lindenmüller et al. 2010). Surgery should only be done when the plaque and gingival inflammation have been controlled.

\section{Knowledge, attitudes and practices of pregnant women}

Poor prenatal care during pregnancy is often associated with women from deprived backgrounds. Such women have practices, attitudes and knowledge based on beliefs, myths and cultural tradition. These false beliefs that pregnancy per se has an adverse effect on the teeth and periodontal tissues lead to a lack of self care and deterioration of the oral health of these women. Evidence suggests that poor oral health can lead to obstetric problems such as low birth weight and preterm delivery (D'Angelo et al.2007, Luce et al. 2011).A number of factors influence visits to the dentist during pregnancy such as social, personal and financial factors and lack of knowledge of the possible connection between oral health and pregnancy outcome (Machuca et al. 1999, Gaffield et al. 2001, Yalcin et al. 2002, Sarlati et al. 2004, Acharya \& Bhat 2009). However, an assessment of pregnant women with a relatively high socioeconomic status in the U.S. found that $49 \%$ of respondents reported having attended a dentist, and $43 \%$ were aware of the connection between oral health and pregnancy outcomes. (Huebner et al.2009. This suggests that better education focused on the importance of dental care before and during pregnancy should be provided to prevent future complications. (Al Habashneh et al. 2005).

We assessed the level of knowledge and oral health practices in pregnant women in a low socioeconomic population in Bogota, Colombia. The study showed that most pregnant women had good knowledge of the major oral diseases and how to prevent them; however, knowledge about the associations between pregnancy and perinatal complications were limited. Over $60 \%$ had attended the dentist during pregnancy and more than $50 \%$ claimed that they had received advice from their doctors and had been recommended to visit their dentist. However, they were not informed about the potential effect of changes in the mouth during pregnancy and the risk for pregnancy complications. In general, these women were from lower socioeconomic communities and the majority of women claimed to brush their teeth frequently and 35\% used dental floss. These women had not perceived significant changes, such as gingival bleeding and swelling, during pregnancy. Women being treated at the community clinic, expressed fears of having radiographs, extractions and local anaesthesia during pregnancy. This study observed a significant improvement in the perception of oral health in a population that regularly attended public services and showed the impact of oral health care guide implemented in these public hospitals and emphasizes the importance of pre-conceptional preventive practices that improve the oral health of 
women before they enter the pregnancy to minimize gingival and periodontal changes associated with this condition.(Lafaurie et al. 2011, unpublished data)

Another factor that influences health care during pregnancy is the low awareness amongst health care professionals of the changes that can occur in the oral cavity during pregnancy.There is clearly a need to provide health personnels with information on the importance of oral care during pregnancy (Al-Habashneh et al. 2008, Huebner et al. 2009, Salama et al. 2010).

\section{Treatment of gingivitis during pregnancy}

Few studies have assessed the effect of treatment on gingivitis during pregnancy. Most studies have evaluated the safety and effect of periodontal treatment on pregnant women with periodontitis. However, Lopez et al. (2005) assessed the safety and effect of treatment of gingivitis during pregnancy and found an increased risk of complications such as pre-term birth (PPT) and low birth weight (LBW) in women who were not treated.

The American Heart Association (AHA) guidelines for prevention of infective endocarditis report that bacteremia associated with oral bacteria was often associated with the patient's routine activities, such as chewing, tooth brushing and after therapeutic procedures (Wilson et al. 2008). Several studies have evaluated the presence of bacteremia in patients by mechanical stimuli such as brushing and flossing (Lockhart et al. 2008, Castra et al. 2009).), chewing (Geerts et al.2002, Ide et al.2004) and ultrasonic scaling (Forner et al. 2006, Kinane et al. 2005). The studies showed that pregnant women with high levels of gingival inflammation can be exposed to bacteremia arising from the mouth.

Once oral bacteria gain access to blood vessels they can cross the placental barrier. Subgingival bacteria increase in pregnancy gingivitis, as it had been reported that Streptococcus ssp. and Fusobacterium nucleatum have been cultured from amniotic fluid in pregnant women (Bearfield et al. 2002). An increase of IgM antibodies to F. nucleatum, P. intermedia and C. rectus in fetal cord blood, were significantly higher for preterm as compared to full-term neonates. It has been suggested that fetal infections by these microorganism may be related to prematurity (Madianos et al. 2001). Fardini et al. (2010) injected bacteria obtained from human saliva and dental plaque into pregnant rats. They demonstrated that a wide range of oral microorganisms may be associated with intrauterine infection.

Given the evidence that periodontal status is associated with complications of pregnancy, some countries have started the implementation of technical standards and guidelines of care which includes oral care during pregnancy. The guideline developed by the State of California has been widely used in clinical practice and has been adapted by other states in the USA (Kumar J, Samuelson 2009). Such guidelines emphasize the need for the care of pregnant women and include the time the treatments to be performed, medications given during pregnancy and indications and contraindications for certain procedures.

The recommendations for periodontal treatment are as follows:

7.1 Dental treatment should be as frequent as possible during the second trimester (weeks 12 to 28) of pregnancy. However, some studies emphasize that gingival inflammation should be reduced early in pregnancy. Treatment, such as scaling and root planing can be performed from week 8 without increased risk for pregnancy (Lopez et al. 2002, 2005).

7.2 Diagnostic X-rays during pregnancy are safe and can improve the assessment of periodontal status. A panel of experts from the Food and Drug Administration (FDA) 
concluded that the recommendations regarding the use of oral radiographs should not be altered because a patient is pregnant (American Dental Association, 2010). The number and type of radiographs depends on the clinical condition and the patient's medical history. As a standard practice for taking radiographs the patient should be protected with a vest that covers the neck and abdomen.

7.3 Most periodontal therapy can be performed with local anesthesia and it is important to note that this does not increase adverse fetal outcomes. Most of the anesthetics used in dentistry are classified as Class B by the FDA. However, mepivacaine and bupivacaine are classified as class $\mathrm{C}$ and are contraindicated in pregnancy. Local anesthetics cross the placental barrier by passive diffusion but are not teratogenic (Hool 2010). Although epinephrine is not teratogenic intravascular injection can be avoided by correctly aspirating with the syringe. (Martin \& Varner 1994). Before the use of vasoconstrictors the blood pressure should be measured because of hypertension during pregnancy occurs between 6 and $10 \%$ of pregnancies.

Although these treatment guidelines exist for pregnant women, there are no specific protocols for the treatment of gingival inflammation in pregnant women. All the evidence, including work from our group, indicates that periodontal treatment can induce a bacteremia in patients with severe periodontal disease (Lafaurie et al. 2007, Castillo et al. 2011). Although most pregnant women have gingivitis during pregnancy the degree of inflammation can vary from mild to severe. The needs for management protocols for pregnant women with have not yet been defined. There are no clear regulations on the use of antiplaque products during pregnancy. Toothpastes containing triclosan have been reported to reduce gingivitis during pregnancy (Kraivaphan et al. 2009). Clorhexidine has been associated with a reduction in cellular proliferation in vitro (Marioti et al. 1999) and desquamation of the mucosa had been reported (Jones 1997). Mouthwashes, such as chlorhexidine, have been used only once a day as part of periodontal therapy in women with gingivitis during pregnany (Lopez et al. 2002, 2005). Based on this evidence it seems beneficial to use mouthwashes and toothpastes containing anti-plaque agents in patients with high levels of gingival inflammation.

\section{Gingival status, gestational diabetes and perinatal complications}

A perinatal risk factor is any biological property, environmental or social, which when present is associated with increased probability of an adverse event, either in the fetus, the mother, or both. Early identification of risk factors may allow strategic planning of prenatal care. Prematurity is the leading cause of neonatal morbidity and mortality worldwide and the frequency varies between populations. The World Health Organization (WHO) in 2000 estimated the prevalence of LBW is approximately $15.5 \%$ (7\% for most developed countries, $16.5 \%$ for those in developing counties. The prevalence determined for each of the regions established by the United Nations was: Africa 14.3\% Asia 18.3\%, 6.4\% Europe, Latin America and the Caribbean 10\%, 7.7\% North America, and Oceania 10.5\%. The risk of a premature infant dying is 180 times greater than that of a full term baby and those that survive have an increased risk of disability. The World Health Organization in 1976 defined low birth weight (LBW) as below 2,500 grams (5.5 pounds) regardless of gestational age and defines pre-term delivery (PPT) as before 37 weeks of gestation.

Many factors have been associated with LBW and PPT. They include socio-demographic factors, maternal age $<18$ and $>35$ years, black race, low socioeconomic status and lack of 
access to health services. All have shown to increase the risk for these perinatal complications (Elster 1984. Buescher \& Mittal 2006, Rosenthal \& Lobel 2011). Other associated factors include a history of PPT prior to 35 weeks gestational age, placental ischemia, premature rupture of membranes and cervical incompetence and complications during pregnancy, such as genito-urinary infections, multiple gestation, bleeding in the second half of pregnancy and polyhydroamnios have been considered as predictors for LBW and PPT ( McCormick 1985, Ferraz et al.1990, Alexander \&. Korenbrot 1995, Kramer et al.1987, Heaman et al. 2008). Aspects related to the lifestyle, the consumption of snuff, alcohol and psychoactive substances and nutritional and psychosocial factors also increase the risk of perinatal complications. (Kogan 1995, Farrell et al.2006, Lederman 2011).

Periodontal status during pregnancy has also been associated with perinatal complications. Numerous cohort studies have been conducted to evaluate the risk association between periodontitis and pregnancy complications (Lopez et al. 2002, Moreu et al. 2004, Pitiphat et al, 2008. Saddki et al. 2008, Agueda et al. 2008). Three systematic reviews demonstrate an increased risk for PPT, LBW and low birth-weight with preterm birth and intrauterine growth restriction in individuals with periodontitis (Xiong et al.2007, Khader \& Ta'ani 2005, Vergnes \& Sixou M 2007). The risk varies between populations but in most studies the presence of periodontitis shown to be an independent risk factor for these complications.

Several studies have identified microorganisms associated with periodontal infections such as P. gingivalis, Actinobacillus actinomycetemcomitans, F. nucleatum. , P. intermedia, T. forsythia and Treponema denticola in samples of placenta of women with preterm labor and preeclampsia. (Barak et al. 2007, León et al. 2007). The proteolytic capacity of these microorganisms and their ability to activate systemic proinflammatory mechanisms, facilitate these perinatal complications. Two periodontal organisms have been specially associated with LBW; C. rectus and P. gingivalis. Rat fetuses exposed to infection with $C$. rectus showed a decreased size and weight compared to a control group (Yeo et al. 2007, Simor et al. 1986, O'Sullivan et al. 1988). Associations between periodontal disease and LBW and PPT were explained also by relating the physiological processes that lead to the time of delivery as periodontal infection lead to increased serum levels of PGE2, TNF, IL 1 13, IL6, which trigger a series event such as cervical dilation, uterine contractions start and the activation of metalloproteinases that generate the breakdown of amniochorion. It seems likely, that periodontal disease could lead to preterm delivery (Damare et al. 1997, Offenbacher et al. 1998, Dörtbudak et al. 2005, Ebersole et al. 2010).

Although a risk association between periodontitis and pregnancy complications is accepted, intervention studies comparing individuals treated with scaling and root planing with a control non treated group have proved to be conflicting. Three trials reported that treatment reduced the complications of pregnancy, (Lopez et al. 2002; Tarannum \&, Faizuddin 2007; Offenbacher et al. 2006). 4 studies in developed countries, however, failed to find an effect on pregnancy complications (Jeffcoat et al. 2005, Michalowicz et al. 2006, Newnham et al. 2009 Offenbacher et al. 2009). However, the studies differed in many respects: The type of population, sample size, presence of other perinatal risks, treatment received and by whom, and the weeks of gestation when the treatment took place. A systematic review (Polyzos et al. 2008 ) which evaluated 7 intervention studies found that scaling and root planing showed a protective effect for PPT OR 0.55 (0.35 to 0.87 ) but not for LBW OR 0.48 (0.23 to 1$)$. The effect of treatment was significantly higher in patients without a history of PPT or LBW OR 
0.48 (0.29 to 0.77$)$ and a mild disease OR 0.49 (0.28 to 0.87$)$. In 2010, the authors included another 3 studies in highly developed countries and show a loss of the protective effect of the periodontal treatment on perinatal complications (Polyzos et al. 2010).

Although the evidence is controversial, the periodontal treatment is a safe procedure and should be performed early in pregnancy between weeks 8 to 28 . However it is important to further evaluate the treatment of advanced periodontal disease in patients with high perinatal risk. The most evidence-based studies show that periodontal treatment during pregnancy reduces further loss of attachment and improves the clinical status of the periodontium during pregnancy.

\section{Periodontal status in high-risk women}

Three conditions must be reviewed in relation to periodontal status and treatment needs during pregnancy.

\subsection{Previous history of preterm delivery (PPT) and low birth weight (BWT)}

The history of PPT and BWT is the most important risk factor for perinatal complications. The evidence indicates that periodontal treatment fails to reduce the incidence of pregnancy complications in patients with a history of PPT and LBW, It, It is necessary to review the protocols for periodontal management in patients with high levels of gingival inflammation. The use of antibiotics in chronic infections during pregnancy has been studied. The evidence indicates that antibiotics are safe during pregnancy and reduce perinatal complications (McDonald et al. 2007). Since gingival inflammation is associated with a polymicrobial flora, broad-spectrum antibiotics may be preferable in the treatment of pregnant women at perinatal risk. Beta-lactam antibiotics such as penicillin and cephalosporins are the drugs of choice. They are categorized as class B drugs by the FDA, cross the placenta, but are considered safe for the fetus (Nahum et al. 2006) If the patient is allergic to penicillin a macrolide antibiotic such as erythromycin, clindamycin and azithromycin, which are rated B by the FDA may be prescribed (Crider et al. 2009). However, antibiotics are only indicated in high-risk perinatal patients with high levels of inflammation and requiring extensive scaling and root planing. The use of antibiotics in these patients is warranted to control the high degree of bacteremia during mechanical treatment. The American Gynecology and Obstetrics Association suggest the following scheme for the prevention of infective endocarditis in pregnant women:

- Ampicillin $2 \mathrm{~g}$ intravenously 1 hour or 30 minutes before the procedure

- Cefazolin $1 \mathrm{~g}$ IV 1 hour or 30 minutes before the procedure

- Amoxicillin 2 g orally 1 hour or 30 minutes before the procedure

- Clindamycin $600 \mathrm{mg} 1$ hour 30 min or earlier in patients who are allergic to penicillin

\subsection{Hypertensive disorders of pregnancy}

The prevalence of hypertension during pregnancy is between 6 and 10\%. Hypertensive diseases and preeclampsia in particular are a cause of morbidity and perinatal and maternal mortality. They are more common in developing countries. The effect of periodontal infection on the incidence of preeclampsia has been evaluated in cohort studies. A systematic review showed an OR 1.76, 95\% CI: 1.43-2.18, in women with preeclampsia compared with pregnant women without preeclampsia; the presence of periodontitis 
increased the risk of perinatal complication (Vergnes et al. 2008). Because of the association between periodontitis and preeclampsia it is important that the periodontal status of pregnant women with preeclampsia risk are assessed in early pregnancy and treated before 20 weeks before presenting the early signs of this condition.

\subsection{Gestational Diabetes}

Gestational Diabetes Mellitus (GDM) is a carbohydrate intolerance of variable severity first recognized during pregnancy. Prevalence of GDM has been reported between 8 al 16\%. (Moses et al. 2001, Chodick et al. 2011). Women with diabetes and with a past history of gestational diabetes, age $>40$ and a body mass index $>35 \mathrm{Kg} / \mathrm{m}$ (BMI) are the most important factors for GDM during pregnancy (Teh et al. 2011). Women with gestational diabetes had a higher mean plaque index and higher mean gingival index than healthy pregnant women (Mittas et al. 2006). Patients with GDM and pregestational obesity had significantly more gingivitis and periodontal attachment loss that those with normal pregestational BMI. (Guthmiller et al. 2001, Chapper et al. 2005). Periodontal treatment should be considered when establishing future recommendations for metabolic control for this group of patients. However, in many cases, the periodontal treatment may be required by patients without good metabolic control with high levels of glycated hemoglobin $(\mathrm{HbA} 1 \mathrm{c}) \geq 8.0)$. In these uncontrolled diabetic patients with active periodontal disease, the first phase of treatment is to reduce levels of inflammation and prevent hyperglycemia produced by pain and stress of infection. The patient should be referred to a physician for a review of their metabolic control (Vermillo 2003.). Well controlled patients may be treated with conventional periodontal treatment. The use of antibiotics for periodontal treatment should be considered in these patients after consultation with their physician. Clinical protocols for gestational Diabetes Mellitus should be developed.

\section{Conclusion and recommendations}

Gingivitis during pregnancy is exacerbated by the hormonal changes that affect the host's responses to dental plaque. Ideally oral health policies and guidelines should be developed for the oral care of women before becoming pregnant. The treatment of gingivitis should commence at an early stage of the pregnancy to minimize the risk of more severe disease at a later stage. However, in high risk patient's treatment of periodontal disease should be undertaken with caution and the use of antibiotics may be recommended. Periodontal treatment improves the oral conditions of pregnant women and could help reduce perinatal complications.

\section{Acknowledgment}

The author would like to express her gratitude to the many people who had added to this chapter and who have been involved in the process. The Administrative Department of Science, Technology and Innovation (Colciencias) (registration number UB-229-2009 Grant 586-2009). Divition investigation from El Bosque University, Bogotá Health Secretary, for all the support. Dra Julieth de Avila who helped in writing and review this chapter. Dra Diana Castillo who was resposable in taking all the photograps, Dra Sandra Vargas, Dra Mayra Gomez and Dr. Frascisco Pereira who participated into the validation of the inquiry of kwoledge and practice in pregnant women. I would like to thank Paula Juliana Martìnez for patiently helping in translating and extensively reviewing the manuscript. 


\section{References}

Acharya S, Bhat PV. Oral-health-related quality of life during pregnancy. (2009) J Public Health Dent;69(2):74-7.

ACOG. ACOG Committee Opinion No. 421, (2008) Antibiotic prophylaxis for infective endocarditis. Obstet Gynecol 112:1193-1194.

Adriaens LM, Alessandri R, Spörri S, Lang NP, Persson GR. (2009) Does pregnancy have an impact on the subgingival microbiota? J Periodontol.80 (1):72-81.

Agbelusi GA, Akinwande JA, Shutti YO. (2000) Oral health status and treatment needs of pregnant women in Lagos State. Niger Postgrad Med J. 7(3):96-100.

Agueda A, Ramón JM, Manau C, Guerrero A, Echeverría JJ. (2008) periodontal disease as a risk factor for adverse pregnancy outcomes: a prospective cohort study. J Clin Periodontol. 35(1):16-22.

Ainamo J, Barmes D, Beagrie G, Cutress T, Martin J, Sardo-Infirri J. (1982) Development of the World Health Organization (WHO) community periodontal index of treatment needs (CPITN). Int Dent J. 32(3):281-91.

Al Habashneh R, Guthmiller JM, Levy S, Johnson GK, Squier C, Dawson DV, Fang Q. (2005) Factors related to utilization of dental services during pregnancy. J Clin Periodontol. 32(7):815-21.

Alexander GR, Korenbrot CC. (1995) The role of prenatal care in preventing low birth weight. Future Child. 5(1):103-20.

Al-Habashneh R, Aljundi SH, Alwaeli HA.(2008) Survey of medical doctors' attitudes and knowledge of the association between oral health and pregnancy outcomes. Int $\mathrm{J}$ Dent Hyg. 6(3):214-20.

Amar S, Chung KM. (1994) Influence of hormonal variation on the periodontium in women. Periodontol 2000. 6:79-87.

American Dental Association, U.S. Food and Drug Administration (2004) The selection of patients for dental radiographic examinations. Disponible en:

"www.ada.org/prof/resources/topics/radiography.asp". Rev. 06/04/2011.

Bainbridge DRJ, Ellis SA, Sargent IL(2000). HLA-G suppresses proliferation of CD4+ T Lymphocytes. J Reprod Immunol. 48:17-26.

Barak S, Oettinger-Barak O, Machtei EE, Sprecher H, Ohel G. (2007) Evidence of periopathogenic microorganisms in placentas of women with preeclampsia. $J$ Periodontol. 78(4):670-76

Bearfield C, Davenport ES, Sivapathasundaram V, Allaker RP. (2002) possible association between amniotic fluid micro-organism infection and microflora in the mouth. BJOG. 109(5):527-33

Buescher PA, Mittal M. (2006) Racial disparities in birth outcomes increase with maternal age: recent data from North Carolina. N C Med J. 67(1):16-20.

Carrillo-de-Albornoz A, Figuero E, Herrera D, Bascones-Martínez A. (2010) Gingival changes during pregnancy: II. Influence of hormonal variations on the subgingival biofilm. J Clin Periodontol. 37(3):230-40..

Castillo DM, Sánchez-Beltrán MC, Castellanos JE, Sanz I, Mayorga-Fayad I, Sanz M, Lafaurie GI (2011). Detection of specific periodontal microorganisms from bacteraemia samples after periodontal therapy using molecular-based diagnostics. $J$ Clin Periodontol. 38(5):418-27. 
Castra K, Daly CG, Mitchell D, Curtis B, Stewart D, Heitz-Mayfield LJ. (2009) Bacteraemia due to dental flossing. Journal of Clinical Periodontol.36 (4):323-32.

Chapper A, Munch A, Schermann C, Piacentini CC, Fasolo MT.(2005) Obesity and periodontal disease in diabetic pregnant women. Braz Oral Res. 19(2):83-7.

Chodick G, Zucker I. Diabetes, (2011) gestational diabetes and the risk of cancer in women: epidemiologic evidence and possible biologic mechanisms. Womens Health (Lond Engl). 7(2):227-37.

Crider KS, Cleves MA, Reefhuis J, Berry RJ, Hobbs CA, Hu DJ.(2009) Antibacterial medication use during pregnancy and risk of birth defects: National Birth Defects Prevention Study. Arch Pediatr Adolesc Med. 163(11):978-85.

Damaré SM, Wells S, Offenbacher S. (1997) Eicosanoids in periodontal diseases: potential for systemic involvement. Adv Exp Med Biol. 433:23-25

D'Angelo D, Williams L, Morrow B, Cox S, Harris N, Harrison L, Posner SF, Hood JR, Zapata L (2004) Preconception and interconception health status of women who recently gave birth to a live-born infant-Pregnancy Risk Assessment Monitoring System (PRAMS), United States, 26 reporting areas, 2004 MMWR Surveill Summ. 14;56 (10):1-35.

Dörtbudak O, Eberhardt R, Ulm M, Persson GR. (2005) Periodontitis, a marker of risk in pregnancy for preterm birth. J Clin Periodontol. 32:45-52.

Ebersole JL, Steffen MJ, Holt SC, Kesavalu L, Chu L, Cappelli D. (2010) Potential pathogenic mechanisms of periodontitis associated pregnancy complications. Clin Exp Immunol. 162:550-9.

Elster AB. (1984) The effect of maternal age, parity, and prenatal care on perinatal outcome in adolescent mothers. Am J Obstet Gynecol. 149(8):845-7.

Fardini Y, Chung P, Dumm R, Joshi N, Han YW. (2010) Transmission of diverse oral bacteria to murine placenta: evidence for the oral microbiome as a potential source of intrauterine infection. Infect Immun. 78(4):1789-96.

Farrell S, Ide M, Wilson RF (2006). The relationship between maternal periodontitis, adverse pregnancy outcome and miscarriage in never smokers. J Clin Periodontol. 33(2):11520.

Ferraz EM, Gray RH, Cunha TM. (1990) Determinants of preterm delivery and intrauterine growth retardation in north-east Brazil. Int J Epidemiol. 19:101-8.

Figuero E, Carrillo-de-Albornoz A, Herrera D, Bascones-Martínez A. (2010) Gingival changes during pregnancy: I Influence of hormonal variations on clinical and immunological parameters. J Clin Periodontol. 37(3):220-29.

Forner L., Larsen T., Kilian M. \&Holmstrup P. (2006) Incidence of bacteremia after chewing, tooth brushing and scaling in individuals with periodontal inflammation.J Clin Periodontol. 33(6): 401-07.

Fournel s, Aguerre-Girr M, Huc X. (2000 ) Soluble HLA-G1 tiggers CD95/CD95 ligand mediated apoptosis in activated CD8+ cells by interacting with CD8+. J Immunol. 164:6100-04.

Gaffield ML, Gilbert BJ, Malvitz DM, Romaguera R. (2001) Oral health during pregnancy: an analysis of information collected by the pregnancy risk assessment monitoring system. J Am Dent Assoc. 132(7):1009-16. 
Geerts SO, Nys M, De MP, Charpentier J, Albert A, Legrand V, Rompen EH. (2002) Systemic release of endotoxinsinduced by gentle mastication: association with periodontitis severity. J Periodontol. 73(1): 73-8.

Gürsoy M, Haraldsson G, Hyvönen M, Sorsa T, Pajukanta R, Könönen E. . (2009) Does the frequency of Prevotella intermedia increase during pregnancy? Oral Microbiol Immunol. 24(4):299-303.

Gürsoy M, Könönen E, Tervahartiala T, Gürsoy UK, Pajukanta R, Sorsa T.(2010) Longitudinal study of salivary proteinases during pregnancy and postpartum. $J$ Periodontal Res. 45(4):496-503.

Gürsoy M, Pajukanta R, Sorsa T, Könönen E. (2008) Clinical changes in periodontium during pregnancy and post- partum J Clin Periodontol. 35(7):576-83.

Guthmiller JM, Hassebroek-Johnson JR, Weenig DR, Johnson GK, Kirchner HL, Kohout FJ, Hunter SK. (2001) Periodontal disease in pregnancy complicated by type 1 diabetes mellitus. J Periodontol. 72(11):1485-90.

Hansen PJ. (1988) Regulation of uterine immune function by progesterones- lessons from the sheep. J reprod immunol 40:63-79.

Health during pregnancy and early childhood: Evidence-based guidelines for health professionals.(2010) J Calif Dent Assoc. 38(6):391-403, 405-40.

Heaman MI, Newburn-Cook CV, Green CG, Elliott LJ, Helewa ME. (2008) inadequate prenatal care and its association with adverse pregnancy outcomes: a comparison of indices. BMC Pregnancy Childbirth. 1: 8-15.

Hool A. Anaesthesia in pregnancy for non-obstetric surgery. (2010) Anaesthesia tutorial of the week 185. Rev. april 62011.

Huebner CE, Milgrom P, Conrad D, Lee RS. (2009) Providing dental care to pregnant patients: a survey of Oregon general dentists. J Am Dent Assoc. 140(2):211-22.

Ide, M., Jagdev, D., Coward, P.Y., Crook, M., Barclay, G.R. \& Wilson, R.F. (2004) The shortterm effects of treatment of chronic periodontitis on circulating levels of endotoxin, C-reactive protein, tumor necrosis factor-alpha, and interleukin-6. J Periodontolo 75 (3):420-28.

Jafarzadeh H, Sanatkhani M, Mohtasham N. (2006) Oral pyogenic granuloma: a review. J Oral Sci. 48(4):167-75.

Jeffcoat MK, Hauth JC, Geurs NC, Reddy MS, Cliver SP, Hodgkins PM, Goldenberg RL.(2003) Periodontal disease and preterm birth: results of a pilot intervention study. J Periodontol. 74(8):1214-8.

Jensen J, Liljemark W, Bloomquist C. (1981) The effect of female sex hormones on subgingival plaque. J Periodontol 52(10):599-602.

Jönsson D. (2007) The biological role of the female sex hormone estrogen in the periodontium--studies on human periodontal ligament cells. Swed Dent J Suppl. (187):11-54.

Jones CG (1997) . Chlorhexidine: is it still the gold standard? Periodontol 2000. 15:55-62,

Kawahara K, Shimazu A. (2003) Expression and intracellular localization of progesterone receptors in cultured human gingival fibroblasts. J Periodontal Res. 38(3):242-6.

Khader YS, Ta'ani Q.(2005) Periodontal diseases and the risk of preterm birth and low birth weight: a meta-analysis. J Periodontol. 76(2):161-5.

Kinane, D.F., Riggio M.P., Walker, K.F., MacKenzie, D. \& Shearer, B. (2005) Bacteremia following periodontal procedures.J Clin Periodontol. 32 (7):,708-13. 
Kinnby B, Matsson L, Astedt B. (1996) Aggravation of gingival inflammatory symptoms during pregnancy associated with the concentration of plasminogen activator inhibitor type 2 (PAI-2) in gingival fluid. J Periodontal Res. 31(4):271-7

Kogan MD. (1995) Social causes of low birth weight. J R Soc Med. 88(11): 611-5

Kornman KS, Loesche WJ. (1980) The subgingival microbial flora during pregnancy. J Periodontal Res. 15(2):111-22.

Kornman KS, Loesche WJ. (1982) Effects of estradiol and progesterone on Bacteroides melaninogenicus and Bacteroides gingivalis. Infect Immun. 35(1):256-63.

Kraivaphan P, Amornchat C, Triratana T. (2007) Effects of a triclosan dentifrice on plaque formation, gingivitis and gingival bleeding in pregnant women: five-month clinical results. Southeast Asian J Trop Med Public Health.;38(3):594-7.

Kramer MS. (1987) Determinants of low birth weight; methodological assessment and metaanalysis. Bull World Health Organ. 65(5):663-737

Kumar J, Samuelson R. (2009) Oral health care during pregnancy and early childhood: practice guidelines. N Y State Dent J. 75(6):29-33.

Lafaurie GI, Mayorga-Fayad I, Torres MF, Castillo DM, Aya MR, Barón A, Hurtado PA. (2007) Periodontopathic microorganisms in peripheric blood after scaling and root planing. J Clin Periodontol .34(10): 873-9.

Laine MA. (2002) Effect of pregnancy on periodontal and dental health. Acta Odontol Scand. 60(5):257-64.

Lapp CA, Lohse JE, Lewis JB, Dickinson DP, Billman M, Hanes PJ, Lapp DF. (2003) the effects of progesterone on matrix metalloproteinases in cultured human gingival fibroblasts. J Periodontol. 74(3):277-88.

Lapp CA, Thomas ME, Lewis JB. (1995) Modulation by progesterone of interleukin-6 production by gingival fibroblasts. J Periodontol. 66(4):279-84.

Lederman RP. (2011) Preterm birth prevention: a mandate for psychosocial assessment. Issues Ment Health Nurs. 32(3):163-9.

León R, Silva N, Ovalle A, Chaparro A, Ahumada A, Gajardo M, Martinez M, Gamonal J. (2007). Detection of Porphyromonas gingivalis in the amniotic fluid in pregnant women with a diagnosis of threatened premature labor. J Periodontol. 78(7):1249-55.

Lindenmüller IH, Noll P, Mameghani T, Walter C. (2010) CO2 laser-assisted treatment of a giant pyogenic granuloma of the gingiva. Int J Dent Hyg. 2010 8(3):249-52.

Liu SH, Al-Shaikh RA, Panossian V, Finerman GA, Lane JM. (1997) Estrogen affects the cellular metabolism of the anterior cruciate ligament. A potential explanation for female athletic injury. Am J Sports Med. 25(5):704-9.

Lockhart PB, Brennan MT, Sasser HC, Fox PC, Paster BJ, Bahrani-Mougeot FK. (2008) Bacteremia associated with toothbrushing and dental extraction. Circulation.117 (24):3118-3125.

López NJ, Da Silva I, Ipinza J, Gutiérrez J.(2005) Periodontal therapy reduces the rate of preterm low birth weight in women with pregnancy-associated gingivitis. $J$ Periodontol. 200576 (11 Suppl):2144-53.

López NJ, Smith PC, Gutierrez J.(2002) Periodontal therapy may reduce the risk of preterm low birth weight in women with periodontal disease: a randomized controlled trial. J Periodontol. 73(8):911-24.

Luce H, Redmer J, Gideonsen M, Dresang L, Potter B, Schrager S.(2011) Culturally specific maternity care in Wisconsin. WMJ. 110(1):32-7. 
Machuca G, Khoshfeiz O, Lacalle JR, Machuca C, Bullón P. (1999) The influence of general health and socio-cultural variables on the periodontal condition of pregnant women. J Periodontol. 1999;70(7):779-85.

Madianos PN, Lieff S, Murtha AP, Boggess KA, Auten RL Jr, Beck JD, Offenbacher S. (2001) Maternal periodontitis and prematurity. Part II: Maternal infection and fetal exposure. Ann Periodontol. 6(1):175-82.

Mariotti A. (1994) Sex steroid hormones and cell dynamics in the periodontium. Crit Rev Oral Biol Med. 5(1):27-53.

Mariotti AJ, Rumpf DA. (1999) Chlorhexidine-induced changes to human gingival fibroblast collagen and non-collagen protein production. J Periodontol. 70(12):1443-8

Markou E, Eleana B, Lazaros T, Antonios K.(2009) The influence of sex steroid hormones on gingiva of women. Open Dent J. 5 (3):114-9.

Martin C, Varner MW. Physiologic changes in pregnancy: surgical implications.(1994) Clin Obstet Gynecol. 37(2):241-55.

McCormick MC. The contribution of low birth weight to infant mortality and childhood morbidity. (1985) N Engl J Med. 312(2):82-90

McDonald HM, Brocklehurst P, Gordon A. (2007) Antibiotics for treating bacterial vaginosis in pregnancy. Cochrane Database Syst Rev. 2007 24;(1):CD000262.

Mealey BL, Moritz AJ. (2003) Hormonal influences: effects of diabetes mellitus and endogenous female sex steroid hormones on the periodontium. Periodontol 2000. 32:59-81.

Michalowicz BS, Hodges JS, Novak MJ et al. Change in periodontitis during pregnancy and the risk of pre-term birth and low birthweight. (2009) J Clin Periodontol. 36(4):308-14

Mittas E, Erevnidou K, Koumantakis E, Papavasileiou S, Helidonis E.(2006) Gingival condition of women with gestational diabetes on a Greek island. Spec Care Dentist. 26(5):214-9.

Miyagi M, Aoyama H, Morishita M, Iwamoto Y. (1992) Effects of sex hormones on chemotaxis of human peripheral polymorphnuclear leukocytes and monocytes. $J$ Periodontol. 63(1):28-32.

Miyazaki H, Yamashita Y, Shirahama R, Goto-Kimura K, Shimada N, Sogame A, Takehara T. (1991) Periodontal condition of pregnant women assessed by CPITN. J Clin Periodontol. 18(10):751-4.

Morani A, Warner M, Gustafsson JA.(2008) Biological functions and clinical implications of oestrogen receptors alfa and beta in epithelial tissues. J Intern Med. 264(2):128-42.

Moreu G, Téllez L, González-Jaranay M. (2005) Relationship between maternal periodontal disease and low-birth-weight pre-term infants. J Clin Periodontol. 32(6):622-7.

Moses RG, Morris GJ, Petocz P, San Gil F, Garg D.(2011) The impact of potential new diagnostic criteria on the prevalence of gestational diabetes mellitus in Australia. Med J Aust. 4;194(7):338-40.

Moss KL, Beck JD, Offenbacher S. (2005) Clinical risk factors associated with incidence and progression of periodontal conditions in pregnant women.(2005) J Clin Periodontol. 32(5):492-8.

Muramatsu Y, Takaesu Y. (1994) Oral health status related to subgingival bacterial flora and sex hormones in saliva during pregnancy. Bull Tokyo Dent Coll. 35(3):139-51.

Nahum GG, Uhl K, Kennedy DL. (2006) Antibiotic use in pregnancy and lactation: what is and is not known about teratogenic and toxic risks. Obstet Gynecol. 107(5):1120-38. 
Newnham JP, Newnham IA, Ball CM, Wright M, Pennell CE, Swain J, Doherty DA. (2009) Treatment of periodontal disease during pregnancy: a randomized controlled trial.(2009) Obstet Gynecol. 114(6):1239-48

Nuamah I, Annan BD.(1998) Periodontal status and oral hygiene practices of pregnant and non-pregnant women. East Afr Med J. 75(12):712-4.

Offenbacher S, Beck JD, Jared HL, Mauriello SM, Mendoza LC, Couper DJ, Stewart DD, Murtha AP, Cochran DL, Dudley Reddy MS, Geurs NC, (2009) Hauth JC; Maternal Oral Therapy to Reduce Obstetric Risk (MOTO R) investigators. Effects of periodontal therapy on rate of preterm delivery: a randomized controlled trial. Obstet Gynecol. 114(3):551-9

Offenbacher S, Jared HL, O'Reilly PG, Wells SR, Salvi GE, Lawrence HP, et al. (1998) Systemic inflammatory responses in progressing periodontitis during pregnancy in a baboon model. Ann Periodontol. 3:233-50.

Offenbacher S, Lin D, Strauss R, McKaig R, Irving J, Barros SP, Moss K, Barrow DA, Hefti A, Beck JD. (2006) Effects of periodontal therapy during pregnancy on periodontal status, biologic parameters, and pregnancy outcomes: a pilot study. J Periodontol. 77(12):2011-24.

O'Sullivan AM, Doré CJ, Boyle S, Coid CR, Johnson AP. (1988) The effect of campylobacter lipopolysaccharide on fetal development in the mouse. J Med Microbiol. 26(2):101-5.

Persson R, Hitti J, Verhelst R, Vaneechoutte M, Persson R, Hirschi R, Weibel M, Rothen M, Temmerman M, Paul K, Eschenbach D. (2009) The vaginal microflora in relation to gingivitis. BMC Infect Dis. 22; 9:6.

Piccini MP. (2005) T cells in pregnancy. Chem Immunol Allergy. 89:3-9

Pitiphat W, Joshipura KJ, Gillman MW, Williams PL, Douglass CW, Rich-Edwards JW. (2008) Maternal periodontitis and adverse pregnancy outcomes. Community Dent Oral Epidemiol. 36(1):3-11.

Polyzos NP, Polyzos IP, Mauri D, Tzioras S, Tsappi M, Cortinovis I, Casazza G. (2009) Effect of periodontal disease treatment during pregnancy on preterm birth incidence: a metaanalysis of randomized trials. Am J Obstet Gynecol. 200(3):225-32.

Polyzos NP, Polyzos IP, Zavos A, Valachis A, Mauri D, Papanikolaou EG, Tzioras S, Weber D, Messinis IE (2010). Obstetric Outcomes after treatment of periodontal disease during pregnancy: systematic review and meta-analysis. BMJ. 29;341:c7017.

Powell JL, Bailey CL, Coopland AT, Otis CN, Frank JL, Meyer I (1994). Nd:YAG laser excision of a giant gingival pyogenic granuloma of pregnancy. Lasers Surg Med. 14(2):178-83.

Rader C, Piorkowski J, Bass DM, Babigian A.(2008) Epulis gravidarum manum: pyogenic granuloma of the hand occurrig in pregnant women. J Hand Surg Am. 33(2):263-5.

Rakchanok N, Amporn D, Yoshida Y, Harun-Or-Rashid M, Sakamoto J. (2010) Dental caries and gingivitis among pregnant an non-pregnant women in Chiang Mai, Thailand. Nagoya J Med Sci. 72(1-2):43-50.

Rosenthal L, Lobel M. (2011) Explaining racial disparities in adverse birth outcomes: Unique sources of stress for Black American women. Soc Sci Med. 72(6):977-83.

Saddki N, Bachok N, Hussain NH, Zainudin SL, Sosroseno W. (2008) The association between maternal periodontitis and low birth weight infants among Malay women. Community Dent Oral Epidemiol. 36(4):296-304 
Salama F, Kebriaei A, McFarland K, Durham T. Prenatal counseling for pregnant women: a survey of general dentists. (2010) J Clin Pediatr Dent. 34(4):291-6.

Sarlati F, Akhondi N, Jahanbakhsh N. (2004) Effect of general health and sociocultural variables on periodontal status of pregnant women. J Int Acad Periodontol. 6(3):95100.

Simor AE, Karmali MA, Jadavji T, Roscoe M. (1986) Abortion and perinatal sepsis associated with campylobacter infection.

Stites DP, Bugbee S, Siiteri PK. (1983) Differential actions ofprogesterone and cortisol on lymphocyte and monocytm interaction during lymphocyte activation - relevance to immunosuppression in pregnancy. J Reprod Immunol 5(4):215-28.

Szekeres-Bartho J, Hadnagy J, Pacsa AS. (1985) Differential actions ofprogesterone and cortisol on lymphocyte and monocyte interaction during lymphocyte activation relevance to immunosuppression in pregnancy. The suppressive effect of progesterone on lymphocyte cytotoxicity: unique progesterone sensivity of pregnan lymphocytes. J Reprod Immunol. 5; 7:121-8.

Tarannum F, Faizuddin M. (2007) Effect of periodontal therapy on pregnancy outcome in women affected by periodontitis. J Periodontol. 78(11):2095-103.

Teh WT, Teede HJ, Paul E, Harrison CL, Wallace EM, Allan C.(2011) Risk factors for gestational diabetes mellitus: implications for the application of screening guidelines. Aust N Z J Obstet Gynaecol. 51(1):26-30.

Tilakaratne A, Soory M, Ranasinghe AW, Corea SM, Ekanayake SL, de Silva M. (2000) Periodontal disease status during pregnancy and 3 months post-partum, in a rural population of Sri-Lankan women. J Clin Periodontol. 27(10):787-92.

Välimaa H, Savolainen S, Soukka T, Silvoniemi P, Mäkelä S, Kujari H, Gustafsson JA, Laine M. (2004) Estrogen receptor-beta is the predominant estrogen receptor subtype in human oral epithelium and salivary glands. J Endocrinol. 180(1):55-62.

Vergnes JN, Sixou M (2007). Preterm low birth weight and maternal periodontal status: a meta-analysis. Am J Obst Gynecol. 196(2):135.e1-7.

Vergnes JN.Studies suggest an association between maternal periodontal disease and preeclampsia.(2008) Evid Based Dent. 9(2):46-7.

Vernillo AT. (2003) Dental considerations for the treatment of patients with diabetes mellitus. J Am Dent Assoc. 134 Spec No:24S-33S

Wandera M, Engebretsen IM, Okullo I, Tumwine JK, Astrøm AN; PROMISE-EBF Study Group. (2009) Socio-demographic factors related to periodontal status and tooth loss of pregnant women in Mbale district, Uganda. BMC Oral Health. 18; 9:18.

Who. Maternal Mortality in 2005. (2007) Estimates developed by WHO, UNICEF, UNFPA and The World Bank. Ginebr Rev. March 182011.

Wilson W, Taubert KA, Gewitz M, Lockhart PB, Baddour LM, Levison M, et al. (2008) Prevention of infective endocarditis: guidelines from the American Heart Association: a guideline from the American Heart Association Rheumatic Fever, Endocarditis and Kawasaki Disease Committee, Council on Cardiovascular Disease in the Young, and the Council on Clinical Cardiology, Council on Cardiovascular Surgery and Anesthesia, and the Quality of Care and Outcomes Research Interdisciplinary Working Group. Journal of American Dental Association.139 Suppl:3S 24S. 
Xiong X, Buekens P, Vastardis S, Yu SM. (2007) Periodontal disease and pregnancy outcomes: state-of-the-science. Obstet Gynecol Surv. 62(9):605-15.

Yalcin F, Eskinazi E, Soydinc M, Basegmez C, Issever H, Isik G, Berber L, Has R, Sabuncu H, Onan U. (2002) The effect of sociocultural status on periodontal conditions in pregnancy. J Periodontol. 73(2):178-82.

Yeo A, Smith MA, Lin D, Riché EL, Moore A, Elter J, Offenbacher S. (2005) Campylobacter rectus mediates growth restriction in pregnant mice. J Periodontol. 76(4):551-7.

Yie SM, Xiao R, Librach CL (2006). Progesterone regulates HLA G though a novel progesterone response element. Hum Reprod. 21:2538-54.

Yokoyama M, Hinode D, Yoshioka M, Fukui M, Tanabe S, Grenier D, Ito HO.(2008) Relationship between Campylobacter rectus and periodontal status during pregnancy. Oral Microbiol Immunol. 23(1):55-9. 


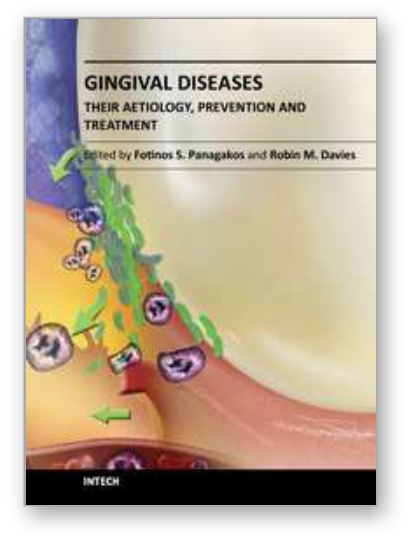

\author{
Gingival Diseases - Their Aetiology, Prevention and Treatment \\ Edited by Dr. Fotinos Panagakos
}

ISBN 978-953-307-376-7

Hard cover, 230 pages

Publisher InTech

Published online 22, September, 2011

Published in print edition September, 2011

Gingival diseases are a family of distinct pathological entities that involve the gingival tissues. These signs and symptoms of these diseases are so prevalent in populations around the world that they are often considered to be â€œnormalâ€ features. The diseases are now classified into two main groups namely: Plaque-Induced and Non-Plaque Induced Gingival Diseases. This book provides dentists, dental hygienists, dental therapists and students with a comprehensive review of gingival diseases, their aetiology and treatment.

\title{
How to reference
}

In order to correctly reference this scholarly work, feel free to copy and paste the following:

Gloria Inés Lafaurie (2011). Gingival Tissue and Pregnancy, Gingival Diseases - Their Aetiology, Prevention and Treatment, Dr. Fotinos Panagakos (Ed.), ISBN: 978-953-307-376-7, InTech, Available from:

$\mathrm{http}: / / w w w . i n t e c h o p e n . c o m / b o o k s / g i n g i v a l-d i s e a s e s-t h e i r-a e t i o l o g y-p r e v e n t i o n-a n d-t r e a t m e n t / g i n g i v a l-t i s s u e-$ and-pregnancy

\section{INTECH}

open science | open minds

\author{
InTech Europe \\ University Campus STeP Ri \\ Slavka Krautzeka 83/A \\ 51000 Rijeka, Croatia \\ Phone: +385 (51) 770447 \\ Fax: +385 (51) 686166 \\ www.intechopen.com
}

\author{
InTech China \\ Unit 405, Office Block, Hotel Equatorial Shanghai \\ No.65, Yan An Road (West), Shanghai, 200040, China \\ 中国上海市延安西路65号上海国际贵都大饭店办公楼 405 单元 \\ Phone: +86-21-62489820 \\ Fax: $+86-21-62489821$
}


(C) 2011 The Author(s). Licensee IntechOpen. This chapter is distributed under the terms of the Creative Commons Attribution-NonCommercialShareAlike-3.0 License, which permits use, distribution and reproduction for non-commercial purposes, provided the original is properly cited and derivative works building on this content are distributed under the same license. 